\title{
The Netherlands
}

\begin{abstract}
The Netherlands' DNA database was legally established in 1994 and became operational in 1997. It represents one of the mid-sized databases in the EU. The Netherlands has a track record of 'innovation' regarding the regulation and practical application of genetic technologies for forensic purposes. The Netherlands was involved with the Prüm regime from its beginnings in 2005. In terms of bordering practices, the country serves as an exemplary case of an expansive and diffusive mode of debordering. This positioning derives from the fact that the Netherlands has been a front-runner in building and implementing the technical framework for Prüm in its most expansive form; it is currently one of the most active countries in the Prüm regime. In addition, the Netherlands has also proactively trained other Member States, guiding them towards effective implementation and thus diffusing the expansive mode of debordering.
\end{abstract}

Keywords The Netherlands $\bullet$ DNA database $\bullet$ Data exchange • Debordering • Prüm 


\section{INTRODUCTION}

The Netherlands' DNA database was legally established in 1994 and became operational in 1997. According to the European Network of Forensic Science Institutes (ENFSI), in June 2016, the database held 237,254 profiles from individuals, which represented 1.4 per cent of the country's population. ${ }^{1}$ In April 2020, the Dutch DNA database held 328,542 profiles from individuals, ${ }^{2}$ which represents 1.9 per cent of the country's population ( of $17,134,178^{3}$ ).

The Netherlands has a track record of 'innovation' regarding the regulation and practical application of genetic technologies for forensic purposes. In 1994, it was the first country to introduce dedicated legislation for the use of forensic DNA to compare DNA profiles from a suspect and from a crime scene (M'charek, Toom, \& Jong, 2020; Toom, 2012a). In 2003 , the Netherlands was also a pioneer in regulating the use of genetically determined externally visible characteristics in criminal investigations (Hopman, 2020; Hopman \& M'charek, 2020; M'charek, 2008). Since then, controversial uses of DNA data, such as forensic DNA phenotyping, familial searching and mass screenings, have gained importance in criminal investigations in the country (Jong \& M'charek, 2017).

The Netherlands was also involved with the Prüm regime from its beginnings in 2005. Now, it is one of the most active countries in the Prüm regime, exchanging DNA data with most operational countries. More particularly, it is connected with all 24 Member States in the system (Council of the European Union, 2020). Dutch bioborders are addressed as an exemplary case of an expansive and diffusive mode of debordering. This position describes the processes by which the Netherlands has been a pioneer in building and implementing the scientific-technical framework for Prüm. In addition, the expansive and diffusive mode of debordering also reflects the Netherlands' role in diffusing the use of DNA data exchange

${ }^{1}$ As the ENFSI report is to our knowledge the latest statistic which provides comparable information across countries, we refer to it to situate the Netherlands in comparison to the other country cases in this study. Data available at http://enfsi.eu/wp-content/ uploads/2017/01/ENFSI-Survey-on-DNA-Databases-in-Europe-June-2016.pdf (last access on 23 June 2020).

${ }^{2}$ Data available at https://dnadatabank.forensischinstituut.nl/resultaten/aantal-profielen-dna-databank-strafzaken (last access on 18 June 2020).

${ }^{3}$ Data available at https://www.worldometers.info/world-population/netherlands-population/ (last access on 23 June 2020). 
by actively assisting other Member States in setting up the techno-scientific and operational infrastructures needed to participate in forensic DNA data exchange. In this, the Netherlands also promotes and guides other countries towards the expansive mode of debordering.

The Netherlands' historical and cultural particularities make it an interesting case in terms of biobordering dynamics. The country has been active in the European unification process from the very beginning. It was one of the six countries that established the European Coal and Steel Community in 1952 and signed the Treaties of Rome in 1957, which established the European Economic Community and the European Atomic Energy Community. The Netherlands was also among the 12 Member States that signed the Treaty of Maastricht, which is considered to be the basis of the European Union (EU). Just as it was among the pioneers of EU integration, the Netherlands is also at the forefront of the techno-scientific development and operational business of forensic DNA technologies and DNA data exchange within the Prüm system.

Public and regulatory debates accompanying the development and implementation of forensic genetic technologies in the Netherlands have brought specific issues to the surface that suggest an entanglement of country-specific idiosyncrasies regarding the national cultural identity. Kešić and Duyvendak have reflected on the notion of 'nativism' in the Netherlands - 'an intense opposition to an internal minority that is seen as a threat to the nation due to its "foreignness" (Kešić \& Duyvendak, 2019 , p. 441) - and how it has combined with Islamophobia, racism and right-wing populism to produce an exclusionary character in recent political and public debates (Kešić \& Duyvendak, 2019, p. 461). In this context, the rape and murder of Marianne Vaatstra has become a 'paradigmatic case' for understanding the materialization of race in public debates, media coverage, regulations and public understandings of forensic DNA technologies (M'charek et al., 2020, p. 2). Identifying the criminal suspect in the case led to a process in which a suspect population (asylum seekers of origin from Iraq and Afghanistan) was socially constructed on the basis of phenotypic differences but the offender was finally confirmed to be of Dutch origin (M'charek et al., 2020, p. 4). The Vaatstra case (described in more detail below) and its materialized forms of biological racism reveal an instance of cultural ideas of nationhood and belonging being translated into forensic genetic technologies. 


\section{National DNA Database Development}

The Dutch DNA database was established under the responsibility of the Ministry of Justice and is, therefore, connected to the Office of the Public Prosecutor. The legislative framework of the Dutch DNA database is regulated by the Code of Criminal Proceedings and the Law on DNA Investigation in Criminal Proceedings (1994, 2001, 2003 and 2005) (Reed \& Syndercombe-Court, 2016). The Dutch legislative framework is organized according to inquisitorial principles-like Germany and Portugal and to some degree Poland-by which forensic evidence is attached to a practice that puts trust in experts, legal professionals and institutes (Toom, 2010b, 2012b). According to this inquisitorial orientation, the Office of Public Prosecution leads the process of criminal investigation, makes the decision on whether to bring legal cases and suspects to court, and prosecutes. Judges actively search for truth during court proceedings and impose sanctions. In the process of drafting and passing laws for forensic DNA profiling, infringements of individual rights and more general legal principles were weighed against the gains of using forensic genetic technologies in the Dutch Parliament (Toom, 2010b, 2012b). In the late 1980s and early 1990s, DNA evidence could only be obtained with the consent of a suspect. In 1994, the Netherlands became the first country to introduce dedicated legislation for the use of forensic DNA to compare DNA profiles from a suspect and from a crime scene (M'charek et al., 2020; Toom, 2012a). The 1994 Forensic DNA Profiling Act (Staatsblad, 1993) rendered suspects of serious crimes (e.g. homicide and sex crimes) subject to mandatory body searches. The same law also set legal provisions for uploading and speculatively searching DNA profiles in a DNA database, determined the period for retention of DNA profiles, and established rules for the deletion of DNA profiles and destruction of reference samples (Koops \& Schellekens, 2008; M'charek, 2008; Toom, 2010a, 2010b; M'charek, Toom, \& Prainsack, 2012). Whereas the 1994 law restricted the use of DNA to capital crimes, such as rape and murder, a 2001 amendment extended the use of DNA profiling to allow individuals suspected of having committed volume crimes to be body-searched to obtain saliva for DNA profiling (M'charek, 2008). This change in the Dutch Forensic DNA legislation was the first step to moving from a restrictive stance to an expansive and extensive use of DNA databases. 
The extensive mode of using forensic DNA databases and DNA analyses for the support of criminal investigation had important steps in the years that followed. Technological advancements in forensic genetics, along with high-profile criminal cases which had unprecedented media coverage and intense public attention, turned the Netherlands into a pioneer in the use of controversial technologies for supporting criminal investigation. One key example is forensic DNA phenotyping that makes it possible to infer some externally visible characteristics of an unknown individual from DNA analysis. In 2003, an amendment to the Dutch law introduced forensic DNA phenotyping. According to some commentators, this change in the Dutch Forensic DNA legislation added race to the features permitted to be determined, therefore widening the scope for forensic genetic technologies from identifying individuals to producing a population to be of interest to be targeted by criminal investigators (M'charek et al., 2020, p. 5).

Currently, the Dutch legislative framework allows DNA samples to be taken and stored in the database for the following categories: profiles of crime scene stains, profiles of suspects involved in a recordable offence ${ }^{4}$ and profiles of persons convicted of a recordable offence. Regarding crime scene stains, police officers are allowed to collect all crime scene DNA stains that possibly belong to a criminal offender. However, they are not authorized to order a DNA analysis of these DNA samples; that power belongs to the public prosecution officer or the judge-commissioner (Reed \& Syndercombe-Court, 2016).

The expansive orientation of the Dutch Forensic DNA legislation is evident in several other aspects, such as the retention regime and the consent for obtaining a body DNA sample from a criminal suspect. Criminal suspects are offered (in writing) the opportunity to voluntarily provide a DNA sample. If the suspect refuses consent, a sample may be taken coercively provided there are serious indications of involvement in a recordable offence. Profiles from suspects may be entered in the database if the suspect is arrested in connection with an offence that can lead to provisional detention or if their inclusion is authorized by an investigating judge or prosecutor. Finally, if convicted individuals refuse consent, samples may also be taken coercively. In terms of retention and deletion criteria, samples from convicted offenders are retained indefinitely and samples of suspects who are acquitted must be destroyed as soon as is reasonably

${ }^{4} \mathrm{~A}$ recordable offence is an offence that in law carries a term of imprisonment. 
practicable. Regarding profiles, unidentified crime scene stains are removed from the database, 10, 20 or 80 years from the date of entry. When suspects are acquitted, their DNA profiles are deleted once the public prosecution office has confirmed that the individual is no longer considered a suspect. Profiles of convicted persons are kept for 20, 30,50 or 80 years, depending on the seriousness of the offence and the conviction (Reed \& Syndercombe-Court, 2016, p. 67).

Regarding the technical database infrastructure, the Dutch DNA database is managed and overseen on behalf of the Minister of Justice by the Director of the Netherlands Forensic Institute (NFI). ${ }^{5}$ The database in the Netherlands uses CODIS (Combined DNA Index System), the IT system developed by the FBI (ENFSI, 2017).

In terms of organizational imperatives and principles, the NFI is externally audited annually for compliance with the Dutch Data Protection Law. Since 2006, the NFI has published an annual report on data relating to the number of profiles inserted in the DNA database, as well as the number of national and international matches (Netherlands Forensic Institute, 2018). These organizational imperatives reflect governance principles committed to notions of public accountability. However, according to Victor Toom (2010a), in contrast with countries like the UK, public discussions with regard to Dutch forensic DNA databasing and its practices have been largely lacking. The influence of organizations involved in policy development and governance (e.g. Dutch Data Protection Authority) is generally minor (Toom, 2012b).

In terms of the development of DNA technology, the Netherlands has a track record of 'innovation' regarding the regulation and practical application of genetic technologies for forensic purposes. New genetic technologies useful for criminal investigation (forensic DNA phenotyping, familial searching and mass screenings) have been authorized for use in police enquiries and have gained importance in criminal investigations in the country (Hopman, 2020; Hopman \& M'charek, 2020; Jong \& M'charek, 2017; M'charek, 2008; Toom, 2006, 2012a).

\footnotetext{
${ }^{5}$ The NFI conducts DNA research and manages the DNA databases of the Caribbean Netherlands (Bonaire, Sint Eustatius and Saba), Aruba, Curaçao and Sint Maarten. From 1 February 2018, it is legally permitted to compare the included single DNA profiles from the DNA databases from the Netherlands, Aruba, Curaçao, St Maarten and Bonaire, Sint Eustatius and Saba. More information available here: https://dnadatabank.forensischinstituut.nl/dna-databanken/dna-databanken-andere-koninkrijksdelen (last access 20 June 2020).
} 
As mentioned earlier in this chapter, the Netherlands became the first country to regulate the use of genetically determined externally visible characteristics in criminal investigations (Staatsblad, 2003). At the time, such traits were sex and race. As pointed out by Victor Toom, " $\mathrm{t}]$ he law was deliberately designed as "window-case legislation" to enable future physical traits to be included in the law, and to enable further genetic research for these purposes' (2012a, p. 162). In 2012 and 2017, additional traits were legalized, respectively, for eye and hair colour (Hopman, 2020). In 2012, new legislation permitted familial searching, that is, searching for relatives to whom an unknown suspect is allegedly genetically related through near matches between DNA profiles, in the national criminal DNA database (van Kooten, Kal, \& Slooten, 2015). The examples of forensic DNA phenotyping and familial searching in the Dutch case illustrate the capacity of contemporary forensic genetics to render 'race' and 'family' as tools to produce leads to support criminal investigation (M'charek et al., 2020). The ethical and social implications of both forensic DNA phenotyping and familial searching are paramount (Granja \& Machado, 2019; Granja, Machado, \& Queirós, 2020).

One element that helps to explain, albeit partially, the innovative orientation of the trajectory of forensic genetic technologies in the Netherlands, and its connections with notions of national identity, is the criminal case of Marianne Vaatstra (briefly described above). In 1999, a girl named Marianne Vaatstra was found murdered in a rural area in the Netherlands. In the absence of a suspect, in 2000, the public prosecutor asked a Dutch forensic laboratory to infer the geographic descent of the unknown perpetrator from a DNA sample found at the crime scene. The inference of personal characteristics from DNA in the criminal justice process was unlawful in the Netherlands at that time. Based on a study of the DNA sample, the forensic laboratory suggested that the offender was most likely a man of North-Western European descent.

In 2007, Marianne's father, on the advice of an expert from a private forensic services company, pushed for familial searching. At the time, the use of this forensic genetic technique was not legally allowed in the Netherlands. However, familial searching technology was considered to be particularly suitable in the Vaatstra case. In 2012 a familial searching in the national DNA database commenced. When this did not provide any leads, a mass screening, in which 8080 men were asked to participate, was announced. During this mass screening, which took place in 2012, a full match was discovered (Jong \& M'charek, 2017). 
The case of the murder of Marianne Vaatstra was a milestone in the regulation of forensic DNA in the Netherlands. Not only did it play a crucial role in the development and implementation of forensic DNA phenotyping, familial searching and mass screenings but it also had an impact on public discourse and political debates about forensic genetic technologies (Jong \& M'charek, 2017; M'charek et al., 2020). The Vaatstra murder became a high-profile case that spoke to national concerns, namely, societal concerns, about the vulnerability of citizens to senseless violence and a lack of safety at night. But the case also became linked to debates on national asylum policy because Marianne was murdered near a centre for asylum seekers. Due to the fact that asylum seekers were initially targeted as probable suspects by part of the local village population, the Vaatstra murder fuelled criticism of xenophobia and racism (Jong \& M'charek, 2017).

\section{Bordering Practices and Transnational DNA DATA ExCHANGE}

The Netherlands was one of the countries, with Belgium, Germany, Spain, France, Luxembourg and Austria, which signed the Prüm Convention on 27 May 2005 agreeing to commence the exchange of data relating to DNA, fingerprints and vehicle registration plates. According to Victor Toom (2018, p. 15), in January 2007, England and the Netherlands began a pilot project outside the Prüm Convention to try to compare the DNA data held on their national databases. The authorities of the Netherlands posted a disk containing 2159 DNA profiles of unsolved crimes to the UK Crown Prosecution Service. These profiles were compared with the almost 4 million DNA profiles held in the national database in the UK and led to 45 potential matches. These matches underwent further testing, and consequently only five were considered to be a real match; the remaining matches were identified as false positive matches. After this initial test, the Netherlands started operating the Prüm system from its inception in 2008. Before the Dutch government ratified the Prüm Convention, it was discussed in both chambers of the Dutch Parliament in 2006 and 2007 (Toom, 2018).

In terms of data border-crossings, the Netherlands exchanges data pertaining to commonly exchanged categories, such as 'convicted individuals', 'suspects' and 'crime stains'. In addition, the Netherlands exchanges 
data on 'unidentified persons', 'unidentified human remains' and 'missing persons', which are among the less common categories to be identified (Council of the European Union, 2020).

In addition to being among the countries that exchange the most data categories, the Netherlands is also one of the most active countries in the Prüm system: it exchanges DNA data with most operational countries (the only exception is Ireland) (Council of the European Union, 2020). The transnational exchange of DNA data within Prüm had, on 1 March 2018, led to 12,323 matches between the Dutch database and the 23 other databases (Toom, 2018). The 2017 annual report on the Dutch DNA database reported that a total number of 12,040 international matches had been made between 2008 and 31 December 2017 (Netherlands Forensic Institute, 2018). Furthermore, the Netherlands has offered the most support to Member States within Prüm, providing practical guidance including evaluation visits to Member States just beginning to exchange DNA data transnationally; the Netherlands has supported six other Member States in this way, while Germany has supported four (Council of the European Union, 2020, pp. 15-19). Dutch experts were part of the supporting teams in Belgium, Denmark, Estonia, Greece, Sweden and UK (Council of the European Union, 2020). Thereby, expert and tacit knowledge about DNA databasing as well as operating transnational DNA data exchange spreads and shapes norms and practices of doing data exchange. The Netherlands-together with Germany-also took the lead in developing the technical framework of the Prüm system: Prüm's software was developed jointly by DNA and IT experts from the Bundeskriminalamt (BKA) in Germany, the Ministry of the Interior of Austria, and the Netherlands Forensic Institute.

The number of categories the Netherlands exchanges and the number of connections its database has with other countries' databases show how the country has been at the forefront of building and implementing the technical framework for Prüm in its most expansive form. Thus, in terms of national legacies of DNA databases and DNA technologies, the Netherlands-due to its extensive experience of DNA databasing and technologies - has performed a dominant and diffusive role in Prüm. Through the technical help it has actively given to other Member States implementing Prüm, it has also guided them towards the expansive mode of debordering.

Dutch forensic experts who have been actively involved in the Prüm system have also made considerable efforts to study and monitor 
cross-border DNA matches between the Netherlands and other operational Member States. The former Dutch custodian of the national DNA database, Kees van der Beek, was the leading DNA scientist and coordinator of the EU Working Party on Information Exchange and Data Protection (DAPIX), which handles work relating to the implementation of legislation and policies on the information exchange and protection of personal data in the field of law enforcement. DAPIX also cooperates closely with Europol, especially regarding the Information Management Strategy (IMS) on streamlining cross-border information exchange.

The dominance of the Netherlands in the Prüm system has also been strengthened by the involvement of Dutch forensic practitioners in certain empirical studies of the implementation, evaluation and strengthening of the structures for the exchange of DNA data in Prüm. One particular relevant example is the PIES (the Prüm Implementation, Evaluation and Strengthening of Forensic DNA Data Exchange) research project, which focused on the cases of Belgium, France, the Netherlands and the UK. The PIES project resulted in particularly relevant studies of cross-border matches between the Netherlands and other Prüm countries (Taverne \& Broeders, 2015) and between the Netherlands and Belgium (Taverne \& Broeders, 2016). One of these studies analysed data provided by the Dutch DNA database custodian for the year 2010 to record the drop-out of cross-border DNA matches. For the year 2010, a total of 2020 matches were found in Prüm Step 1 (the automated exchange of DNA profiles) for the Dutch database (Taverne \& Broeders, 2015). Only 138 (6.8 per cent) of the matches resulted in a request for mutual legal assistance (Prüm Step 2 ), and those hits led to 37 ( 1.8 per cent) matches being used in a prosecution (see also Toom, 2018).

Among the motifs and notions of nationhood mobilized in complying with the Prüm system is the Netherlands' performance of the leading role in encouraging other countries to join the Prüm system and take advantage of the benefits of using the DNA profiles stored in the Dutch DNA database. The Netherlands' role in the development and diffusion of the Prüm system is fuelled by the impact of many success stories from the Prüm regime (Prainsack \& Toom, 2010). One example of the Netherlands as the 'triumphant hero' in the transnational exchange of DNA data is the following story of a criminal case solved by the Prüm system, which is very popular among forensic practitioners who support its expansion: 
On 21 May 2015, an elderly couple of 75 and 74 years were found at their home in Vienna. The Austrian police found the DNA of the alleged killer, but no matches in the national DNA database. However, under the Prüm system, a match was found in the Dutch DNA database with a 29-year-old man from Poland. Having the name of the person-Dariusz Pawel Kotwica-the Austrian authorities could start looking for him. The suspect was arrested on June 8 at the railway station of Düsseldorf, in Germany. After his extradition to Austria, Kotwica also confessed to a murder in Sweden, committed a few weeks earlier, and attempted murder in Salzburg. Under Prüm, several other EU countries started running the Polish forensic DNA database to see if it matched samples found at the scenes of unsolved crimes. The media reported that there was a strong suspicion that Kotwica had also committed serious crimes in the United Kingdom, Czech Republic, and the Netherlands. The media renamed the case as the 'Euro-ripper' case, and hurled headlines like 'Europe's first cross-continental serial killer'. (Machado \& Granja, 2018)

Toom and colleagues have reported another case that put the Dutch forensic DNA database and its role in the Prüm system at the forefront (Toom, Granja, \& Ludwig, 2019, p. 50):

On 22 March 2016, a bomb was detonated at Maalbeek station in Brussels, killing twenty people. In connection with the criminal investigation, automatic rifles were found in a house near Paris two days later. After reexamining the rifles in early 2018 , biological traces were collected and DNA profiles were obtained. The profiles were uploaded to the French national DNA database and, on account of the Prüm Decisions, compared with DNA profiles held on national DNA databases connected to the Prüm system. The cross-border comparison led to matches with three individuals whose DNA profiles were held on the Dutch DNA database. The suspects were arrested in the Netherlands on 18 June 2018.

The tacit claim of these two criminal cases is that the removal of obstacles to the circulation of DNA data between countries created extraordinary opportunities for solving serious murders that might otherwise have remained unsolved. In this context, the matches found in the Dutch DNA database are presented as 'heroic' in the public sphere and among the inner circles of policy-makers and promoters of the Prüm system.

The Netherlands' mode of biobordering therefore sheds light into the diffusive mode of debordering as it reflects the Netherlands' role in assisting other Member States to set up the technologies and IT infrastructures 
needed to participate in forensic DNA data exchange. The Netherlands' diffusive mode of debordering is also expressed in the commitment to study and monitor cross-border DNA matches between the Netherlands and other operational Member States within Prüm. Furthermore, as one of the more active countries in the transnational exchange of DNA data, considering the speed of developing connections, number of connections established with other countries and number and type of data categories exchanged, the Netherlands is also considered as an example of an expansive mode of debordering. Diffusive debordering here, therefore, refers to the spread of expert and tacit knowledge about operating data exchange, spreading technology standards, monitoring practices as a form of control mechanism and leading by example.

\section{REFERENCES}

Council of the European Union. (2020). Working party on JHA Information Exchange (IXIM) 5322/19. Brussels

ENFSI. (2017). DNA database management. Review and recommendation. Retrieved from http://enfsi.eu/wp-content/uploads/2016/09/final_version_enfsi_2016_document_on_dna-database_management_0.pdf

Granja, R., \& Machado, H. (2019). Ethical controversies of familial searching: The views of stakeholders in the United Kingdom and in Poland. Science, Technology, \& Human Values, 44(6), 1068-1092.

Granja, R., Machado, H., \& Queirós, F. (2020). The (De)materialization of criminal bodies in forensic DNA phenotyping. Body \& Society. https://doi.org/1 $0.1177 / 1357034 X 20919168$

Hopman, R. (2020). Opening up forensic DNA phenotyping: The logics of accuracy, commonality and valuing. New Genetics and Society, 1-17. https://doi. org/10.1080/14636778.2020.1755638

Hopman, R., \& M'charek, A. (2020). Facing the unknown suspect: Forensic DNA phenotyping and the oscillation between the individual and the collective. BioSocieties, 1-25. https://doi.org/10.1057/s41292-020-00190-9

Jong, L., \& M'charek, A. (2017). The high-profile case as 'fire object': Following the Marianne Vaatstra murder case through the media. Crime, Media, Culture: An International Journal, 14(3), 347-363. https://doi. org/10.1177/1741659017718036

Kešić, J., \& Duyvendak, J. W. (2019). The nation under threat: Secularist, racial and populist nativism in the Netherlands. Patterns of Prejudice, 53(5), 441-463. https://doi.org/10.1080/0031322X.2019.1656886

Koops, B.-J., \& Schellekens, M. (2008). Forensic DNA phenotyping: Regulatory issues. The Columbia Science and Technology Law Review, IX, 158-202. 
M'charek, A. (2008). Silent witness, articulate collective: DNA evidence and the inference of visible traits. Bioethics, 22(9), 519-528. https://doi. org/10.1111/j.1467-8519.2008.00699.x

M'charek, A., Toom, V., \& Jong, L. (2020). The trouble with race in forensic identification. Science, Technology, \& Human Values, 1-25. https://doi. org/10.1177/0162243919899467

M'charek, A., Toom, V., \& Prainsack, B. (2012). Bracketing off population does not advance ethical reflection on EVCs: A reply to Kayser and Schneider. Forensic Science International: Genetics, 6, el6-e17. https://doi. org/10.1016/j.fsigen.2010.12.012

Machado, H., \& Granja, R. (2018). Ethics in transnational forensic DNA data exchange in the EU: Constructing boundaries and managing controversies. Science as Culture, 27(2), 242-264. https://doi.org/10.1080/0950543 1.2018 .1425385

Netherlands Forensic Institute. (2018). Jaarverslag 2017: Nederlandse DNA-databank.

Prainsack, B., \& Toom, V. (2010). The Prum regime. Situated dis/empowerment in transnational DNA profile exchange. British Journal of Criminology, 50(6), 1117-1135. https://doi.org/10.1093/bjc/azq055

Reed, K., \& Syndercombe-Court, D. (2016). A comparative andit of legislative frameworks within the European Union for the collection, retention and use of forensic DNA profiles. London: EUROFORGEN. Retrieved from https:// www.euroforgen.eu/fileadmin/websites/euroforgen/images/Dissemination Documents/WP4/Reed_and_Syndercombe_Court_2016_Legal_Audit.pdf

Staatsblad. (1993). Wet van 8 november 1993 van de regeling van het DNAonderzoek in strafzaken (Besluit DNA-onderzoeken) [Law of 8 November 1993 regarding DNA research for criminal proceedings (Forensic DNA Profiling Act)]. Staatsblad van Het Koninkrijk Der Nederlanden, 522, 1-17

Staatsblad. (2003). Wet van 8 mei 2003 tot wijziging van de regeling van het DNA-onderzoek in strafzaken in verband met het vaststellen van uiterlijk waarneembare persoonskenmerken uit celmateriaal [Law of 8 May 2003 regarding changes of the law on DNA research in criminal p. Staatsblad van Het Koninkrijk Der Nederlanden, 201, 1-2

Taverne, M., \& Broeders, A. P. A. (2015). The light's at the end of the funnel! Evaluating the effectiveness of the transnational exchange of DNA profiles between the Netherlands and other Prüm countries. Zutphen: Paris Legal Publishers.

Taverne, M., \& Broeders, A. P. A. (2016). Cross-border patterns in DNA matches between the Netherlands and Belgium. Science \& Justice, 00(00), 1-7. https:// doi.org/10.1016/j.scijus.2016.08.008

Toom, V. (2006). DNA fingerprinting and the right to inviolability of the body and bodily integrity in the Netherlands: Convincing evidence and proliferating 
body parts. Genomics, Society and Policy, 2(3), 64-74. https://doi. org/10.1186/1746-5354-2-3-64

Toom, V. (2010a). Carriers of truth. Normative aspects of twenty years of DNA profiling in the Netherlands. PhD Thesis. Faculty of Social and Behavioural Sciences, Amsterdam Institute for Social Science Research, University of Amsterdam, The Netherlands. Retrieved from https://dare.uva.nl/ search?identifier $=3 a 725371-a 6 c 5-4 d e 3-83 c e-a 526 b a 64 f c f 8$

Toom, V. (2010b). Inquisitorial forensic DNA profiling in the Netherlands. In R. Hindmarsh \& B. Prainsack (Eds.), Genetic suspects: Global governance of DNA profiling and databasing (pp. 175-196). Cambridge University Press.

Toom, V. (2012a). Bodies of science and law: Forensic DNA profiling, biological bodies, and biopower. Journal of Law and Society, 39(1), 150-166.

Toom, V. (2012b). Forensic DNA databases in England and the Netherlands: Governance, structure and performance compared. New Genetics and Society, 31(3), 311-322. https://doi.org/10.1080/14636778.2012.687133

Toom, V. (2018). Cross-border exchange and comparison of forensic DNA data in the context of the Prüm Decision. Civil liberties, justice and home affairs. Retrieved from http://www.europarl.europa.eu/thinktank/en/document. html?reference=IPOL_STU(2018)604971

Toom, V., Granja, R., \& Ludwig, A. (2019). The Prüm decisions as an aspirational regime: Reviewing a decade of cross-border exchange and comparison of forensic DNA data. Forensic Science International: Genetics, 41, 50-57. https://doi. org/10.1016/j.fsigen.2019.03.023

van Kooten, C., Kal, A., \& Slooten, K. (2015). Three years of familial searching in the Netherlands: Results and lessons learned. Retrieved from https://dnadatabank.forensischinstituut.nl/documenten/publicaties/2018/11/01/ three-years-of-familial-searching-in-the-netherlands-results-and-lessons-learned 
Open Access This chapter is licensed under the terms of the Creative Commons Attribution 4.0 International License (http://creativecommons.org/licenses/ by $/ 4.0 /)$, which permits use, sharing, adaptation, distribution and reproduction in any medium or format, as long as you give appropriate credit to the original author(s) and the source, provide a link to the Creative Commons licence and indicate if changes were made.

The images or other third party material in this chapter are included in the chapter's Creative Commons licence, unless indicated otherwise in a credit line to the material. If material is not included in the chapter's Creative Commons licence and your intended use is not permitted by statutory regulation or exceeds the permitted use, you will need to obtain permission directly from the copyright holder. 